\title{
Intersections
}

Canadian Journal of Music

Revue canadienne de musique

\section{Nina Sun Eidsheim. 2015. Sensing Sound: Singing and Listening as Vibrational Practice. Durham, NC: Duke University Press, 270 pp. ISBN 978-0-8223-6046-9 (hardcover), ISBN 978-0-8223-6061-2 (paperback), ISBN 978-0-8223-7469-5 (e-book)}

\section{Daniel Akira Stadnicki}

Volume 36, numéro 2, 2016

URI : https://id.erudit.org/iderudit/1051607ar

DOI : https://doi.org/10.7202/1051607ar

Aller au sommaire du numéro

Éditeur(s)

Canadian University Music Society / Société de musique des universités canadiennes

ISSN

1911-0146 (imprimé)

1918-512X (numérique)

Découvrir la revue

Citer ce compte rendu

Stadnicki, D. A. (2016). Compte rendu de [Nina Sun Eidsheim. 2015. Sensing Sound: Singing and Listening as Vibrational Practice. Durham, NC: Duke University Press, 270 pp. ISBN 978-0-8223-6046-9 (hardcover), ISBN

978-0-8223-6061-2 (paperback), ISBN 978-0-8223-7469-5 (e-book)]. Intersections, 36(2), 135-138. https://doi.org/10.7202/1051607ar

Copyright (C Canadian University Music Society / Société de musique des universités canadiennes, 2018
Ce document est protégé par la loi sur le droit d'auteur. L'utilisation des services d'Érudit (y compris la reproduction) est assujettie à sa politique d'utilisation que vous pouvez consulter en ligne.

https://apropos.erudit.org/fr/usagers/politique-dutilisation/ 
Nina Sun Eidsheim. 2015. Sensing Sound: Singing and Listening as Vibrational Practice. Durham, NC: Duke University Press, 270 pp. ISBN 978-0-8223-6046-9 (hardcover), ISBN 978-0-8223-6061-2 (paperback), ISBN 978-0-8223-7469-5 (e-book).

Located somewhere on the periphery of semiotics, performance-, sound-, voice-, and affect studies, Sensing Sound delivers a provocative theory of musical sonority-one that interrogates the participatory, material, and experiential dimensions of music-making in new and exciting ways. Published as part of Duke University Press's Sign, Storage, and Transmission series, Nina Sun Eidsheim's contribution is a welcome addition to a lineup of influential titles, bridging the series' focus on sound and material culture by engaging with the inter-materialities of vocal sound and performance. But as the interest in sound studies only seems to grow with each passing year, the book also serves as a timely re-examination of this vast and somewhat ambiguous field of research. It challenges how sound studies defines its object (188n7), questioning the prioritization of the aural sensory mode over other domains. Adopting a more comprehensive and multimodal approach to musical sound, Eidsheim unpacks the concept of the figure of sound; highlighting case studies from the world of contemporary Western opera that contradict the internal logic of this governing aural paradigm. Written from the "perspective of performance and practice" (163), the book seeks to "recover the dynamic, multisensorial phenomenon of music" (3); arguing that "not only aurality but also tactile, spatial, physical, material, and vibrational sensations are at the core of all music" (8).

The book is divided into five chapters, each grappling with the figure of sound through the lens of "materiality and its multisensory dimension" (48). Here, 'materiality' indicates a range of processes and interactions that collectively make up the embodied "activity and experience" (129) of vocal sound. Drawing critical insight from acoustic, physiological, cognitive, and linguistic perspectives, Eidsheim puts forward a theory of music as vibrational practice to demonstrate complex relationality, emphasizing dynamics of "process, articulation, and change across material" (17). This approach allows for a more generous view of musical sound as the culmination of material interactions between spaces, bodies, performers, and audiences; a movement away from "thinking about music as a knowable aesthetic object to thinking about it as transferable energy" (16). In many respects, the vibrational thesis is a significant expansion of Eidsheim's research on vocal timbre, ${ }^{1}$ which generated

1 See Eidsheim, Nina Sun. "Synthesizing Race: Towards an Analysis of the Performativity of Vocal Timbre," Trans: Revista Transcultural de Música 13 (2009), 1-11; and "Voice as Action: Toward 
powerful connections between the social categorization and racialization of the voice as shaped by a multitude of a priori assumptions and 'extra-sonic' information. ${ }^{2}$ By focusing on the non-aural factors of musical sound and the more paradoxical activities inherent to music-making, each chapter attempts to gain a material understanding of not only the voice, but also what gives rise to musical meaning, signification, and aestheticization.

But what exactly is the figure of sound? On the one hand, it articulates how aurality has been the chief parameter for interpreting and discussing musical sound as a knowable, measurable, and objective phenomenon. Eidsheim reminds us how in the academy, audition has traditionally been the domain for music scholarship, causing "our vocabulary and orientation" to be "primarily attuned and confined to that domain" (4). But aurality alone cannot account for the 'thick event' of music, which encompasses multiple, seemingly indiscernible interactions that are nevertheless "sensed by the material, lived body" (51). Hence, musical sound is often quickly rendered into an object, divorced from performance context and listening experience. Consequentially, the effect of the figure of sound extends far beyond issues of scholarly rhetoric and discourse, impacting all forms of musicking: it not only "shape[s] how we discuss, conceive of, and analyze music, but it also determines the ways in which we imagine we can relate to music and the power we imagine it to wield in our lives" (6). In this way, unpacking the figure of sound operates at the level of ideological critique, as the tendency towards audition alone obscures the role of other sensory modes and material processes, leading to fetishization. Since we can only recognize the figure when we become conscious of a sound's 'nonnormative' features (61), Eidsheim stresses the need to 'denaturalize music's parameters' (22) through encouraging the "idiosyncratic experiences of and with music" (10). This exercise is done by focusing each chapter around extreme, interdisciplinary case studies that reveal isolated musical parameters that are masked by the figure of sound.

In Chapter One, Eidsheim reconsiders the status of air as the "default medium for the material transmission of sound" (57), citing the underwater performances of opera singer Juliana Snapper as a point of departure. Articulating perhaps the first step of denaturalization by addressing the "material dependency" of sound (49), the chapter examines the physical properties of air and water through Snapper's work, arguing that our aural experience and evaluation of sound is profoundly tied to the materiality of its production and "predicated on our physical contact with sound waves through shared media" (44). Moving to issues of space, Chapter Two offers the most compelling theoretical argument in the book, broadening Christopher Small's concept of musicking to include acoustic, spatial, and intermaterial factors. Investigating the "spatial characteristics of sound" (78), Eidsheim deliberates on the reification of the figure in the places where vocal sound is often performed and

a Model for Analyzing the Dynamic Construction of the Racialized Voice," Current Musicology 93 (Spring 2012), 9-33.

2 Eidsheim 2012, 11. 
experienced (i.e. the traditional concert hall). From this vantage point, public concert spaces represent complex sites for musicking activities that "experientially reify" (59) the figure of sound. For instance, acousticians use languages that serve to match the figure of sound in ideal concert halls (66); composers "write with [a] particular acoustics in mind" (62); and listeners form aesthetic judgements according to their distance and positioning from the performed sound source, typically facing a stage in a two-dimensional seated position (68). As such, our aesthetic evaluations are shaped "by a body trained in spatial-relational acoustics and encultured to orient itself to the figure of sound" (94). Eidsheim also dedicates considerable analysis and reflection on Meredith Monk and the Vocal Ensemble's Songs of Ascension (2008), as well as a staging of Christopher Cerrone's Invisible Cities (2013) - both of which encouraged radical uses of space, audience participation and interaction.

Both Chapters Three and Four elaborate upon the "materialities that influence vocal sound" (112), using case studies drawn from Eidsheim's artistic practice and experiments in vocal pedagogy. Focusing on the theme of 'music and action,' Chapter Three evokes the theme of materiality to indicate the embodied, physiological and cognitive parameters engaged in the sounding of voice-aspects that are rarely considered in the figure of sound, which favours the aural voice "over the physical events that give rise to them" (124). Two of her featured projects, Body Music and Noisy Clothes, focus on movement and the "internal, invisible choreographies that yields vocal sounds." (111) Other examples include voluntary and involuntary bodily movement, as well as non-linguistic sounds ('ums,' 'ahs,' stuttering, etc.) (100)—representing how "vocalizing bodies remain active" (101) despite the interpretive tendency to approach them as outside of vocalization, or as linguistic signs of a 'failed voice' if vocalization "hinges upon making sense" (99). These points are elucidated in the chapter's opening study on the SpeechJammer device and Richard Serra's Boomerang, where participants become unexpectedly overwhelmed when hearing their own voice in a delayed playback. Thus, vocalization only appears to fail (stuttering, pauses, etc.) because the preferred (fetishized) vocal sounds are interrupted.

Exploring vocal pedagogy and the "vocal labor recruited to maintain a piece's identity and status" (134), Chapter Four pinpoints timbre as a crucial feature for understanding how vocalists learn to adhere to the sound ideals of a given musical work. For Eidsheim, the ways in which a singer is trained can perpetuate the idea "that music and voice consist of sound, not physiological matters" (138); potentially reifying the figure of sound and "the work status of an entire musical tradition" (136) if the relationship between a work's timbral ideal and a vocalist's ability to reproduce it is obscured when teaching is grounded in replicating sound, not physiological activity. Eidsheim challenges the dominance of aurality in vocal training, offering aerobic, movement-based exercises and non-judgemental experiments with vocal sound to shift emphasis away from the "resultant sound to the actions that produce it" (146).

As the fifth and final chapter summarizes the book's intermaterial thesis, Eidsheim reiterates how a vibrational theory of music can have profound 
implications for future scholarship. Hinting at the potential for developing an "organology of intermaterial vibration" (163), the theory is certainly not limited to vocal performance, either. But in laying the groundwork for what could be described as a material philosophy of vocal sound, Eidsheim raises interesting questions about how intermaterial processes can invite notions of the pre-symbolic: they are the "perceptive and instinctual" (160) parameters; the basic and immediate encounters with sound as pure feeling and jouissance (159) that are later integrated into the symbolic order. In effect, each chapter 'stages' pre-symbolic encounters with sound to both challenge the aural paradigm and to encourage new theories of vibrational signification. The inclusion of distinct, even obvious musical case studies helps to clearly demonstrate the contours of Eidsheim's theory, but its future applications need not be restricted to contemporary, experimental performance. The multisensory experience of musical sound can, and should be approached vibrationally across genres and styles. Reflecting a form of scholarship that necessitates playful and practical engagements with music and voice, Sensing Sound is sure to enliven music and sound studies research for years to come. Now, who's up for the task?

DANiel AKIRA STADNicki

\section{Bibliography}

Eidsheim, Nina. 2009. "Synthesizing Race: Towards an Analysis of the Performativity of Vocal Timbre," Trans: Revista Transcultural de Música 13, $1-11$.

- 2012. "Voice as Action: Toward a Model for Analyzing the Dynamic Construction of the Racialized Voice," Current Musicology 93 (Spring): 9-33.

\section{BIOGRAPHY}

Daniel Akira Stadnicki is a PhD Candidate (Ethnomusicology) and World/Popular Music Instructor based at the University of Alberta. His dissertation research is supported by a Vanier Canada Graduate Scholarship, focusing on musical narratives of Iranian Baha'i persecution. Daniel specializes in the study of 2oth and 21st century music and politics, devotional aesthetics, and informal music pedagogies, recently publishing in both the Journal of Popular Music Education and the Journal of Interdisciplinary Voice Studies. In addition to his scholarly work, Daniel records and performs internationally as a drummer/percussionist. For more information, please visit www.danielstadnicki.com. 